\title{
Studi Kerapatan Kerang Kima (Tridacnidae) Di Pulau Pramuka dan Pulau Belanda, Kepulauan Seribu, DKI Jakarta
}

\author{
Maryanti Setyaningsih ${ }^{1}$, Hayati Amali ${ }^{2}$, Susilo ${ }^{3)}$ \\ ${ }^{1}$ Pendidikan Biologi, Fakultas Keguruan dan Ilmu Pendidikan, Universitas Muhammadiyah Prof. DR. HAMKA \\ E-mail: maryanti.setyaningsih@uhamka.ac.id \\ ${ }^{2}$ Pendidikan Biologi, Fakultas Keguruan dan Ilmu Pendidikan, Universitas Muhammadiyah Prof. DR. HAMKA \\ E-mail: hayatiamali@ymail.com \\ ${ }^{3}$ Pendidikan Biologi, Fakultas Keguruan dan Ilmu Pendidikan, Universitas Muhammadiyah Prof. DR. HAMKA \\ E-mail: susilo@uhamka.ac.id
}

APA Citation: Setyaningsih, M., Amali, H., Susilo. (2019). Studi Kerapatan Kerang Kima (Tridacnidae) di Pulau Pramuka dan Pulau Belanda, Kepulauan Seribu, DKI Jakarta. Quagga: Jurnal Pendidikan dan Biologi, 11(2), 188-193, doi: 10.25134/quagga.v12i2.2186.

Received: 01-01-2020

Accepted: 4-06-2020

Published: 01-07-2020

\begin{abstract}
Abstrak: Status populasi kima di beberapa bagian dunia telah menjadi perhatian khusus para peneliti biota laut. Kerang kima mengalami tenakan antropogenik, sehingga studi mengenai status populasinya sangat diperlukan. Penelitian ini bertujuan untuk mepresentasikan status konservasi dan jumlah populasi kerang kima di Pulau Pramuka dan Pulai Belanda, Kepulauan Seribu DKI Jakarta. Penelitian ini dilaksanakan pada Bulan MaretApril 2016. Teknik Sampling yang digunakan adalah Purposive sampling dengan menggunakan Belt Transect. Analisis data menggunakan pengukuran Kerapatan (K), Kerapatan Relatif (KR). Hasil penelitian, ditemukan 27 individu dari 3 spesies di Pulau Belanda dan 8 individu dari 1 spesies di Pulau Pramuka. Pulau Belanda memiliki Kerapatan individu kerang kima lebih tinggi dari Pulau Pramuka dengan $K=0.1 \mathrm{ind} / \mathrm{m}^{2}$ dan Kerapatan Relatif spesies tertinggi adalah Sp1 (KR=70\%) diikuti Sp3 (KR=20\%) dan Sp2 (KR=10\%) dengan nilai $R=0.60$ dan memiliki dominansi terendah yaitu $C=0.47$. Sedangkan Pulau Pramuka Kerapatan individu terendah $0.03 \mathrm{ind} / \mathrm{m}^{2}$, dengan nilai $R=0$ dan $C=1$. Hal ini menunjukkan Pulau Belanda memiliki kerapatan dan kekayaan spesis kerang kima lebih tinggi dari Pulau Pramuka tetapi tidak ada spesies yang mendominansi. Pulau Pramuka memiliki kerapatan dan kekayaan spesies yang rendah tetapi dominansi spesies yang tinggi dikarenakan hanya ditemukan 1 spesies di Pulau Pramuka yaitu Sp1.
\end{abstract}

Keywords: kerapatan; kerang kima; tridacnidae; kepulauan seribu.

\begin{abstract}
This research aims to compare the abundance of clams on Pramuka Island and Dutch Island, Thousand Islands, DKI Jakarta. The study was conducted in March-April 2016. The Sampling technique used is Purposive sampling using a Belt Transect. Data analysis uses measurement of abundance (K), relative abundance (KR), Species Wealth Index (R), Simpson Dominansi Index (C) and species Similarity Index (S). The results of the study, found 27 individuals from 3 species on the Dutch island and 8 individuals from 1 species in Pramuka Island. The Dutch island has an individual abundance of clams higher than the Pramuka island with $K=0.1 \mathrm{ind} / \mathrm{m} 2$ and the relative abundance of the highest species is Sp1 $(K R=70 \%)$ Followed by Sp3 $(K R=20 \%)$ and $\operatorname{Sp} 2(K R=10 \%)$ With the value $R=0.60$ and has the lowest dominancy of $C=0.47$. Whereas Pramuka Island is the lowest individual abundance of $0.03 \mathrm{ind} / \mathrm{m} 2$, with values of $R=0$ and $C=1$. This shows the island of the Netherlands has an abundance and wealth of species of clams kima higher than the island Scout but there are no other dominates. Pramuka Island has the abundance and wealth of low species but the high species dominancy because only found 1 species in Pramuka Island namely Sp1.
\end{abstract}

Keywords: Abundance; clams; Tridacnidae; Thousand Islands.

\section{PENDAHULUAN}

Kepulauan seribu di Provinsi DKI Jakarta dengan potensi bahari terumbu karang, memiliki daya tarik bagi setiap unsur masyarakat (Noviana, 2018). Terumbu karang sebagai ekosistem memiliki arti besar bagi kehidpan biota laut (Adi,
Damar, Adrianto, \& Sudarma dan Akhmad Solihin, 2017). Kerang Kima merupakan salah satu biota laut yang hidup di sekitar terumbu karang (Ghufron \& Kordi, 2011). Kelimpahan terumbu karang di Kepulauan seribu tidak terlepas dari keberadaan kerang kima di 
sekitarnya (Toonen, Nakayama, Ogawa, Rossiter, \& Delbeek, 2012). Keindahan warna cangkang kerang kima membuatnya menjadi kerang unik diantara spesies kerang lain (Ghufron \& Kordi, 2011).

Ukuran cangkangnya yang relatif besar dan berat, membuat kerang kima disebut sebagai kerang raksasa (giant clams) (Ghufron \& Kordi, 2011). Kerang kima (Tridacnidae) hidup bersimbiosis dengan ganggang dinofalgellata, dan zooxanthella yang hidup di mantel kima ( $\underline{\mathrm{Soo}}$ \& Todd, 2014). Keberadaan zooxanthella membuat kebutuhan akan cahaya matahari sangat tinggi, dan cahaya matahari merupakan faktor penting yang dibutuhkan untuk berlangsungnya proses fotosintesis bagi zooxanthella yang hidup di mantel kima (Soo \& Todd, 2014). Selain fotosintesis, kerang kima juga memperoleh energi dengan Filter feeding atau menyaring perairan (Castro \& Huber, 2008). Karenan kemampuan filter feeding, kerang kima dianggap sebagai biofilter alami bagi lautan.

Manfaat lain dari kerang kima adalah seluruh bagian tubuhnya baik daging maupun cangkang dapat dimanfaatkan. Daging kima marupakan bahan makanan yang sangat lezat sementara cangkang kima dapat digunakan sebagai wadah, hiasan, dan bahan baku untuk industri keramik (Ghufron \& Kordi, 2011). Cangkang Kima juga berperan dalam pembibitan untuk ikan melalui kandungan kalsium karbonat, serta menyediakan perlindungan spasial untuk epibion, polychaetes dan spons (Soo \& Todd, 2014).

Meskipun kerang kima memiliki peran ekologis yang penting, status konservasi mereka terbilang mengkhawatirkan (Neo et al., 2017). Eksploitasi liar menjadi penyebab utama menurunnya populasi kerang kima (Wynsberge et al., 2017). Sebagian besar spesies kerang kima dieksploitasi untuk konsumsi atau penggunaan cangkangnya sebagai barang rumah tangga biasa (Susiana, Ningsih, \& Amran, 2014). Studi yang dilakukan Othman, Goh, \& Todd, (2010) mengungkapkan bahwa hilangnya habitat, polusi, dan peningkatan suhu permukaan laut juga menjadi penyebab menurunnya populasi kerang kima. Van Wynsberge et al., (2016) menemukan bahwa kelimpahan populasi kima berhubungan erat dengan populasi manusia per area terumbu.

Studi terkait mengenai populasi kerang kima telah banyak dilakukan, diantaranya pengamatan yang dilakukan Yusuf, Ambariyanto, \& Hartati,
(2009) ditemukan total 167 individu kima di garis transek sepanjang 100 meter di Kepulauan seribu. (Hasni, Sadarun, \& Ira, 2017) menyatakan bahwa rendahnya keanekaragaman kima (indeks 0,28$0,47)$ juga terjadi di Pulau Wawosunggu Konawe Selatan. Tidak hanya di Indonesia, menurunnya populasi kima juga terjadi di beberapa negara dengan eksploitasi historis yang tinggi (Neo et al., 2017). Eksploitasi terus menjadi ancaman utama dan tantangan konservasi bagi kerang kima. Penurunan populasi kerang kima juga terjadi di Laut merah, (Ullmann, 2013) menemukan bahwa daerah pantai dangkal yang mudah diakses manusia didominansi oleh kerang kecil. Konklusi dari beberapa penelitan terdahulu menemukan bahwa populasi kerang kima telah menurun akibat eksploitasi yang tidak diikuti dengan budidaya.

Rendahnya populasi kerang kima di Pulau Pramuka diduga disebabkan oleh budaya dan kebiasaan masyarakat Pulau Pramuka yang mengkonsumsi kerang kima. Ancaman akan populasi kima di Kepulaun Seribu diduga bukan hanya terjadi di Pulau Pramuka tetapi pulau lainnya yaitu Pulau Belanda. Walau Pulau Belanda masuk ke zona inti 3 yang menjadi tempat konservasi terumbu karang akan tetapi, ancaman akan menurunnya populasi kerang kima tidak dapat dihindari. Lokasi Pulau Belanda yang berdekatan dengan pulau penduduk yaitu Pulau Harapan dan Pulau Kelapa memungkinkan terjadinya pengambilan daging kima yang dapat mengancam berkurangnya populasi kerang kima.

Studi ini dimaksudkan untuk mepresentasikan status konservasi dan jumlah populasi kerang kima di Pulau Pramuka dan Pulai Belanda, Kepulauan Seribu DKI Jakarta. Data yang diperoleh diharapkan mampu menjadi bahan evaluasi dan informasi bagi pemerintah setempat dalam mengambil kebijakan pengelolaan sumber daya pesisir dan laut khususnya kerang kima.

\section{METODOLOGI PENELITIAN}

Penelitian ini dilakukan di perairan Pulau Pramuka dengan titik kordinat antara $05^{\circ} 45^{\prime}$ LS 106 $37^{\prime}$ BT dan Pulau Belanda dengan titik kordinat antara $05^{0} 36^{\prime}$ LS - 106 $036^{\prime}$ 'BT Taman Nasional Laut Kepulauan Seribu. Penelitian ini dilaksanakan pada Bulan Maret-April 2016.

Teknik sampling yang digunakan adalah Purposive Sampling dan menggunakan Belt Transect. Belt transect diletakkan di 4 titik pengamatan berdasarknan arah mata angin. 
Panjang transek yang digunakan adalah 10 meter dan lebar 1 meter ke kiri dan 1 meter ke kanan (Fachrul, 2007) setiap titik atau stasiun terdapat 3 Belt transect dengan jarak interval pertransek 10 meter. Luas bidang yang teramati pertranseknya yaitu $20 \mathrm{~m}^{2}$. Semua biota kerang kima yang berada di dalam belt transect dihitung jumlahnya.

Sampel yang didapat kemudian di foto dan diidentifikasi langsung di lapangan menggunakan buku identifikasi "Gaint Clams in Asia and The Pacific" (Lucas \& Copland, 1988)dan buku "Moluska Padang lamun" (LIPI Press:2008). Identifikasi langsung dikarenakan spesies yang didapat tidak boleh diambil karena statusnya yang dilindungi. Identifikasi sampel sampai tingkat spesies dimana spesies yang ditemukan diberi kode. $S p 1$ (untuk spesies yang mirip dengan kima lubang Tridacna crocea), $S p 2$ (untuk spesies yang mirip dengan kima sisik Tridacna squamosa), Sp3 (untuk spesies yang mirip kima pasir Hippopus hippopus).

Pengambilan contoh air (parameter biologi, fisika dan kimia) diukur secara insitu dilakukan pada setiap stasiun pengamatan dan parameter yang diamati hanya pada pengukuran suhu, kedalaman, $\mathrm{pH}$ dan kecerahan. Pengukuran suhu menggunakan thermometer air raksa, pengukuran kedalaman menggunakan patok kedalaman, pengukuran $\mathrm{pH}$ menggunakan kertas $\mathrm{pH}$ dan pengukuran kecerahan menggunakan sechi disk.

Data hasil penelitian dianalisis dan disajikan dalam bentuk tabel dan grafik. Kerapatan (K), Kerapatan Relatif(KR), Indeks Kekayaan Spesies (R), Indeks Dominansi Simpson (C) dan Indeks Kesamaan Spesies $(S)$. Kerapatan kerang kima yang ditemukan pada suatu lokasi pengamatan per satuan luas transek pengamatan (Suin, 2012) menggunakan rumus:

$$
\text { K Jenis } A=\frac{\text { Jumlah Individu Jenis A }}{\text { Iumlah unit contoh }}
$$

Hasil penilitan berupa data fisik, akan diperkuat dengan hasil wawancara berupa deskripsi atau pemaparan fakta lapangan yang sesuai dengan pengalaman masyarakat setempat mengenai keberadaan dan konsumsi kerang kima.

\section{HASIL DAN PEMBAHASAN}

Parameter lingkungan perairan di Pulau Pramuka dan Pulau Belanda Kepuluan Seribu. Untuk lebih jelasnya liat tabel berikut ini.
Tabel 1. Perbandingan Paremeter Perairan Pulau Pramuka dan Pulau Belanda

\begin{tabular}{lccc}
\hline \multicolumn{1}{c}{ Parameter } & $\begin{array}{c}\text { Pulau } \\
\text { Pramuka }\end{array}$ & $\begin{array}{c}\text { Pulau } \\
\text { Belanda }\end{array}$ & $\begin{array}{c}\text { Standar } \\
\text { Baku Mutu }\end{array}$ \\
\hline Suhu $\left({ }^{0} \mathrm{C}\right)$ & 28 & 29 & $28-30$ \\
pH & 6 & 6 & $7-8,5$ \\
Kedalaman (m) & 3 & 1 & $>5$ \\
Kecerahan $(\mathrm{m})$ & 11,6 & 12,6 & Alami \\
Substrat & Rock & Rock & Alami \\
\hline
\end{tabular}

\section{Jumlah Individu Kerang Kima}

Hasil penelitian yang didapat setelah melakukan pengambilan data selama 3 kali ulangan didua lokasi yaitu Pulau Pramuka dan Pulau Belanda didapatkan 8 individu kerang kima di Pulau Pramuka dan 27 individu kerang kima di Pulau Belanda. Untuk lebih jelasnya dapat dilihat pada tabel dibawah ini:

Tabel 2. Hasil Identifikasi Kerang Kima di Pulau Pramuka dan Pulau Belanda.

\begin{tabular}{cccc}
\hline \multirow{2}{*}{ Genus } & Spesies & \multicolumn{2}{c}{ Lokasi } \\
\cline { 3 - 4 } Tridacna & & $\begin{array}{c}\text { Pulau } \\
\text { Pramuka }\end{array}$ & $\begin{array}{c}\text { Pulau } \\
\text { Belanda }\end{array}$ \\
& Sp 2 & 8 & 17 \\
Hippopus & Sp 3 & 0 & 4 \\
Jumlah & & 8 & 6 \\
\hline
\end{tabular}

Lubang), Sp2 (Kima Sisik), Sp3 (Kima Pasir).

\section{Kerapatan Kerang Kima}

Hasil penelitian menunjukkan bahwa kerapatan kerang kima lebih tinggi di Pulau Belanda dari pada di Pulau Pramuka. Dengan kepadatan individu $/ \mathrm{m}^{2}$. Data hasil penghitungan perbandingan kerapatan kerang kima (Tridacnidae) di perairan Pulau Pramuka dan Pulau Belanda untuk lebih jelasnya dapat dilihat pada tabel dibawah ini:

Tabel 3. Kerapatan Kerang Kima (Individu/ $\mathrm{m}^{2}$ ) Pada Masing-Masing Lokasi Pengamatan.

\begin{tabular}{ccc}
\hline Jenis & Pulau Belanda & Pulau Pramuka \\
\hline Sp 1 & 0.07 & 0.03 \\
Sp 2 & 0.01 & 0 \\
Sp 3 & 0.02 & 0 \\
Total & 0.1 & 0.03 \\
\hline
\end{tabular}

Keterangan : Sp1 (Kima Lubang), Sp2 (Kima Sisik), Sp3 (Kima Pasir). 


\section{Kerapatan Relatif Kerang Kima}

Kerapatan relatif kerang kima di Pulau Pramuka berkisar $100 \%$ hal ini dikarenakan hanya ditemukan 1 spesies saja yaitu $S p 1$, sedangkan di Pulau Belanda berkisar 70 \%-10\%.

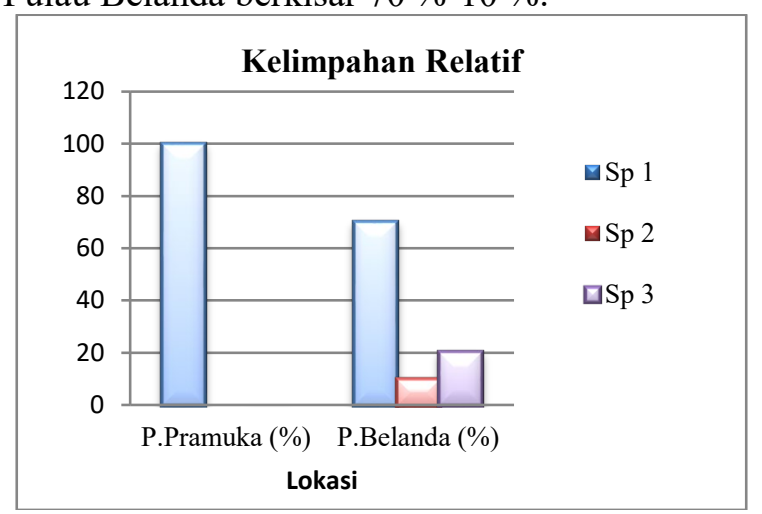

Gambar 1. Kerapatan kerang kima

\section{Indeks Kesamaan, Kekayaan dan Dominansi}

Pulau Belanda memiliki nilai indeks kekayaan spesies $\mathrm{R}=0.60$. dengan nilai indeks Dominasnis $\mathrm{C}=0.40$.

\section{Pembahasan}

Hasil penelitian menunjukkan bahwa, Pulau Belanda memiliki jumlah individu kerang kima dan jenis yang tinggi yaitu 27 individu dari 3 jenis kerang kima. Sedangkan di Pulau Pramuka ditemukan 8 individu dan hanya ada 1 jenis kerang kima. Dari nilai yang tertera di atas dapat dilihat bahwa penyebaran kerang kima pada kedua lokasi adalah tidak sama, perbedaan jumlah spesies kima di Pulau Pramuka dan Pulau Belanda bukan disebabkan oleh faktor lingkungan, karena berdasarkan hasil pengukuran paramater lingkungan (Tabel 1) menunjukan bahwa Pulau Pramuka dan Pulau Belanda masih memiliki parameter lingkungan yang mendukung bagi kehidupan kerang kima. Kisaran suhu di kedua lokasi menunjukan angka $28-29^{\circ} \mathrm{C}$, suhu pada kisaran ini baik bagi pertumbuhan kima. Hasil ini didukung oleh (Braley, 1992), suhu optimum bagi pertumbuhan kima berkisar $25-32^{\circ} \mathrm{C}$. Rendahnya individu kima di Pulau Pramuka diasumsikan karena adanya aktivitas manusia yang memanfaatkan atau mengeksploitasi spesies kima dengan cara yang kurang baik.

Hasil penelitian berupa data fisik diperkuat dengan hasil wawancara dengan masyarakat setempat bahwa mereka memiliki tradisi dimana, setiap perayaan Idul Fitri masyarakat Pulau Pramuka akan menyediakan olahan daging kima dan ketupat, sehingga terjadi pengambilan daging kima secara besar-besaran saat mendekati Idul Fitri. Tingginya tingkat eksploitasi kima tidak sejalan dengan perkembangan kima di alam, hal ini dikarenakan kima membutuhkan waktu pertumbuhan yang cukup lama. Menurut (Lucas \& Copland, 1988), tingkat perkembangan awal remaja kima sangat lambat, mereka membutuhkan beberapa bulan atau lebih untuk mencapai panjang cangkang beberapa milimeter, mungkin selama setahun panjang cangkang hanya 20-40 mm.

\section{Kepadatan Kerang Kima}

Bila dilihat berdasarkan kepadatan jenis SpI memiliki nilai kepadatan relatif lebih tinggi dibandingkan dengan ke 2 jenis lainnya, yaitu sebesar $0.07 \mathrm{ind} / \mathrm{m}^{2}$ di Pulau Belanda dan 0.03 ind $/ \mathrm{m}^{2}$ di Pulau Pramuka.

Tingginya nilai kepadatan dari jenis ini kemungkinan disebabkan ukurannya yang kecil dan berhubungan erat dengan cara hidupnya yang membenamkan seluruh cangkangnya pada celahcelah batu karang sehingga membuat jenis ini sulit untuk diambil oleh manusia dan secara alami juga terlindungi dari hempasan ombak. Sedangkan kedua jenis lainnya yang dibeberapa stasiun tidak ditemukan diduga telah habis diambil oleh masyarakat sekitar karena sifat mereka yang hanya melekat lemah pada substrat pasir maupun patahan karang.

\section{Kerapatan Relatif Kerang Kima}

Hasil penelitian mengenai kerapatan realtif kerang kima dapat dilihat pada (Gambar 1) menunjukkan bahwa nilai kerapatan realatif tertinggi terdapat pada jenis $S p l$ sebesar $100 \%$ di Pulau Pramuka dan $70 \%$ di Pulau Belanda. Sedangkan kerapatan realtif terendah pada jenis $S p 2$ sebesar 10\%. Tingginya kerapatan jenis $S p 1$ disebabkan oleh tipe substrat di kedua lokasi yang dominan dengan batuan (Rock) Spl di temukan menempel di karang massif (coral massive) dan batuan (Rock) dan seluruh cangkangnya terbenam di dalam substat yang keras yaitu di karang massif (coral massive) dan batuan (Rock).

Hal ini juga didukung oleh (Marzuki, Sadarun, \& Palupi, 2013), spesies kima yaitu Tridacna crocea atau kima lubang adalah spesies menempel pada kerang masif (coral massive) dan seluruh cangkangnya terbenam di dalam substrat yang keras yaitu pada coral massive yang hidup 
atau yang sudah mati. (Hermawan, 2012), juga mengatakan bahwa T.crocea ditemukan di terumbu karang dan cangkangnya benar-benar terbenam di batu karang dan hanya mantelnya saja yang terlihat oleh penyelam $S p 2$ adalah jenis kerang kima dengan tingkat kerapatan relatif terendah yaitu hanya sebesar $10 \%$. Rendahnya tingkat kerapatan relatif ini kemungkinan dipengaruhi dari jenis substrat yang terdapat pada ke dua lokasi yang didominasi oleh batuan (Rock) Spl di temukan menempel di karang massif (coral massive), sedangkan $S p 2$ yang ditemukan hidup pada substrat kerang hidup dan patahan karang.

\section{Indeks Kesamaan, Kekayaan Spesies dan Dominansi}

Kesamaan spesies di kedua lokasi Pulau Pramuka dan Pulau Belanda, nilai yang didapatkan yaitu 0.5. Hasil tersebut menunjukkan nilai tersebut mendekati nilai 0 menurut kriteria kesamaan spesies (Suheriyanto, 2008) yang berarti kesamaan spesies dari kedua lokasi pengamatan tergolong rendah. Rendahnya kesamaan spesies antara dua lokasi kemungkinan dipengaruhi oleh tingginya tingkat ekploitasi kerang kima di Pulau Pramuka dibandingkan di Pulau Belanda.

Kekayaan spesies dari kedua lokasi berdasarkan hasil penelitian menunjukkan bahwa kekayaan spesies tertinggi berada di Pulau Belanda sebasar $\mathrm{R}=0.60$ dan Pulau Pramuka menunjukkan angka $\mathrm{R}=0$ hal ini kemungkinan dikarenakan hanya satu spesies yang ditemukan di Pulau Pramuka dan spesies yang ditemukan adalah spesies yang sulit untuk diambil oleh masyarakat yaitu spesies yang seluruh cangkangnya terbenam di batuan dan karang, sedangkan spesies yang lain yang ditemukan di Pulau Belanda tetapi tidak ditemukan di Pulau Pramuka yaitu $s p 2$ dan $s p 3$ diduga sudah langka karena spesies ini sangat mudah untuk diambil karena cara hidupnya yang hanya menempel sedikit di karang atau pasir sehingga sangat mudah untuk diambil oleh masyarakat. Hasil ini didukung oleh Hermawan, (2012), habitat dari kima pasir adalah di daerah berpasir.

Nilai dominansi tertinggi adalah Pulau Pramuka menunjukkan angka $\mathrm{C}=1$ hal ini menyatakan bahwa di Pulau Pramuka hanya ada satu spesies yang mendominansi, berkurangnya spesies yang lain yang kemungkinan disebabkan pengambilan oleh masyarakat membuat spesies satu ini menjadi spesies yang dominan. Sedangkan di Pulau Belanda menunjukkan angka $\mathrm{C}=0.40$ rendahnya nilai dominansi menyatakan bahwa Pulau Belanda tidak ada spesies kerang kima yang mendominansi hal ini kemungkinan disebabkan oleh kondisi lingkungan pada keempat lokasi di Pulau Belanda mampu mendukung berbagai jenis kehidupan, sehingga tidak terjadi persaingan pada kondisi ekstrim yang dapat menimbulkan dominansi spesies, dan masih terjaganya lingkungan Pulau Belanda dari pengambilan kima yang dilakukan masyarakat sehingga kekayaan spesies lebih tinggi dari Pulau Pramuka.

\section{SIMPULAN}

Kerapatan kerang kima di Pulau Belanda 0.1 ind $/ \mathrm{m}^{2}$ sedangkan Pulau Pramuka $0.03 \mathrm{ind} / \mathrm{m}^{2}$. Kekayaan spesies tertinggi adalah di Pulau Belanda berkisar $\mathrm{R}=0.60$ ditemukan 3 spesies kerang kima sedangkan Pulau Pramuka $\mathrm{R}=0$ karena hanya ditemukan 1 spesies kerang kima. Sedangkan Spesies yang mendominansi dari kedua lokasi adalah Kima Lubang.

\section{REFERENSI}

Adi, N. D., Damar, A., Adrianto, L., \& Sudarma dan Akhmad Solihin, D. (2017). Strategi Pengelolaan Terumbu Karang Di Kepulauan Seribu. Jurnal Pengelolaan Sumberdaya Alam Dan Lingkungan, 7(3), 244-250. https://doi.org/10.19081/jps1.2017.7.3.244

Braley, R. D. (1992). The Giant Clam:Hetchery and Nursery Culture Manual. Australia: ACIAR Monograph.

Castro, P., \& Huber, M. E. (2008). Mariene Biology (Seventh Ed). New York: McGraw-Hill.

Fachrul, M. F. (2007). Metode Sampling Bioekologi. Jakarta: Bumi Aksara.

Ghufron, H., \& Kordi, K. M. (2011). Ekosistem Lamun (seegres). Jakarta: Rineka Cipta.

Hasni, Sadarun, B., \& Ira. (2017). Keanekaragaman dan Kepadatan Jenis Kima di Perairan Pulau Wawosunggu Kabupaten Konawe Selatan. Sapa Laut, 2(4), 113-118.

Hermawan, U. E. (2012). Taxonomy of Indonesia Giant Clams(Cardiidae,Tridacnina). Pusat Kelautan Oseanografi LIPI. Jurnal Biodiversitas. Vol. 13 (3): 118-123., 13(3), 
118-123.

Lucas, J. S., \& Copland, J. W. (1988). Giant Clams in Asia and the Pacific. Canberra: ACIAR Monograph Series.

Marzuki, I. D., Sadarun, B., \& Palupi, R. D. (2013). Kondisi Terumbu Karang dan Kelimpahan Kima di Perairan Pulau Indo. Jurnal Mina Laut Indonesia, 1(1).

Neo, M. L., Wabnitz, C. C. C., Braley, R. D., Heslinga, G. A., Fauvelot, C., Van Wynsberge, S., ... Todd, P. A. (2017). Giant clams (Bivalvia: Cardiidae: Tridacninae): A comprehensive update of species and their distribution, current threats and conservation status. Oceanography and Marine Biology: An Annual Review, 55(1965), 87-154. https://doi.org/10.1201/b21944.

Noviana, L. (2018). Studi Ekosistem Terumbu Karang di Taman Nasional Kepulauan Seribu. Jurnal Pengelolaan Sumberdaya Alam Dan Lingkungan (Journal of Natural Resources and Environmental Management), 9(2), 352-365. https://doi.org/10.29244/jpsl.9.2.352-365

Othman, A. S. Bin, Goh, G. H. S., \& Todd, P. A. (2010). The distribution and status of giant clams (family Tridacnidae) - A short review. Raffles Bulletin of Zoology, 58(1), 103-111.

Soo, P., \& Todd, P. A. (2014). The behaviour of giant clams (Bivalvia: Cardiidae: Tridacninae). Marine Biology, 161(12), 2699-2717. https://doi.org/10.1007/s00227-014-25450 .

Suheriyanto, D. (2008). Ekologi Serangga. Malang: UIN Malang Press.

Suin, N. M. (2012). Ekologi Hewan Tanah. Jakarta: Bumi Aksara.

Susiana, S., Ningsih, A., \& Amran, M. A. (2014). Kelimpahan Dan Kepadatan Kima (Tridacnidae) Di Kepulauan Spermonde. Agrikan: Jurnal Ilmiah Agribisnis Dan Perikanan, 6(3), 55-64. https://doi.org/10.29239/j.agrikan.6.0.55-

61.

Toonen, R. J., Nakayama, T., Ogawa, T., Rossiter, A., \& Delbeek, J. C. (2012). Growth of cultured giant clams (Tridacna spp.) in low $\mathrm{pH}$, high-nutrient seawater: Speciesspecific effects of substrate and supplemental feeding under acidification. Journal of the Marine Biological Association of the United Kingdom, 92(4), 731-740.

https://doi.org/10.1017/S00253154110007 62.

Ullmann, J. (2013). Population status of giant clams (Mollusca: Tridacnidae) in the northern Red Sea, Egypt. Zoology in the Middle East, 59(3), 253-260. https://doi.org/10.1080/09397140.2013.84 2307.

Van Wynsberge, S., Andréfouët, S., GaertnerMazouni, N., Wabnitz, C. C. C., Gilbert, A., Remoissenet, G., ... Fauvelot, C. (2016). Drivers of density for the exploited giant clam Tridacna maxima: a metaanalysis. Fish and Fisheries, 17(3), 567584. https://doi.org/10.1111/faf.12127

Wynsberge, S. Van, Andréfouët, S., GaertnerMazouni, N., Wabnitz, C. C. C., Menoud, M., Le Moullac, G., ... Remoissenet, G. (2017). Growth, survival and reproduction of the giant clam tridacna maxima (Röding 1798, Bivalvia) in two contrasting lagoons in French Polynesia. PLoS ONE, 12(1), 120.

https://doi.org/10.1371/journal.pone.01705 65.

Yusuf, C., Ambariyanto, \& Hartati. (2009). Abundance of Tridacna (Family Tridacnidae) at Seribu Island And Manado Waters, Indonesia. Jurnal Ilmu Kelautan Universitas Diponegoro (UNDIP)., 14. 